line has preceded the counting of it in the male line, and we are also shown good reason for excepting the statement that descent in the female line is necessarily a sign

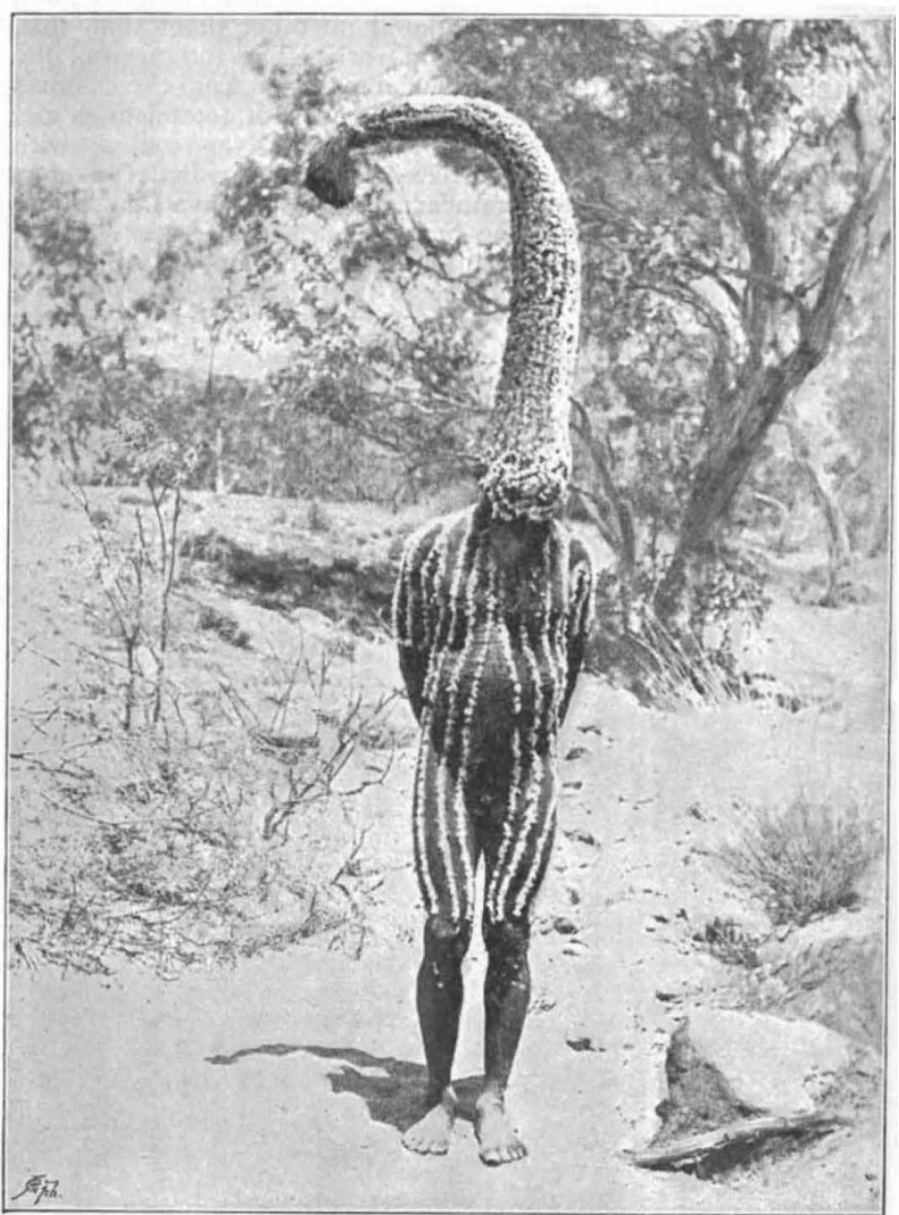

FIG. 2.-Ceremony of the Emu Totem; the head-dress represents the neck and head of an emu.

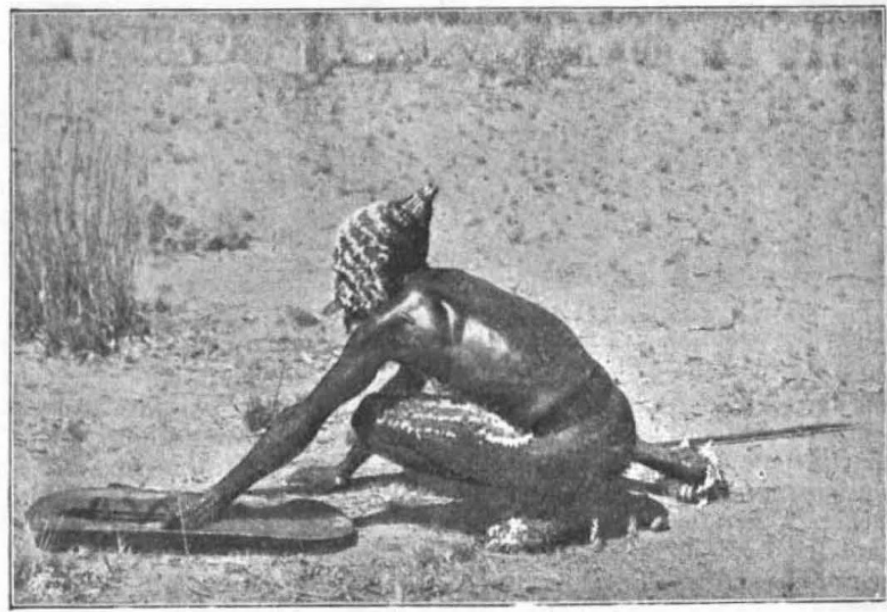

FIG. 3.- Kurdaitcha creeping up to his enemy. Between his teeth he holds a small stone Churinga; the shoes are seen on his feet, and in his left hand he holds a shield and two or three wooden Churinga.

of primitiveness. Perhaps the divergences in the customs recorded of some of these Central Australian tribes

NO. I 535 , VOL. 59] may have a connection with the traditional wanderings of their Achilpa ancestors, concerning which we are provided with detailed accounts and maps of the routes followed. The fact, that the ancestors came from the south-west and south-east, and found themselves among already located peoples, looks as if the northern immigration having crossed Australia and reached the extreme confines of the continent had rolled back on its tracks. Every group of natives appears to have its local head man; this position he attains on account of his skill in hunting or fighting, or his knowledge of the ancient traditions of the tribe; such a man will consult the elders of his tribe, but the final disposition of all points rests in his hands: no stranger will enter the camp without his permission; should he have no son to succeed him he appears to have the power to nominate the individual he desires to be his successor-in other words he is in a primitive fashion chief of his group. On the other hand, the natives do not appear to have arrived at that state where a chief of a tribe becomes a necessity. We are glad to see the authors take a stand against the common assertion that the Australian aboriginal is degenerate ; no assertion can be wider the mark, for we have no evidence to show that the Australian was ever in a higher state of civilisation than that in which he is now found.

The book, suitably dedicated to the founders of Australian anthropology, is a solid piece of work of altogether exceptional merit. In the above remarks we have only been able to point out a few of its more salient features; but there is a mass of information we have not touched upon, and which will gladden the heart of the anthropological student. The excellent illustrations of the ceremonies, evidently obtained with much care, patience and difficulty, are of considerable assistance to the text ; the glossary fulfils its purpose, and the index is good.

Hy. LING RoTH.

SIR DOUGLAS GALTON, K.C.B., F.R.S. GIR DOUGLAS GALTON, whose death $S$ we regret to have to record, was for many years one of the best-known men not only in scientific circles but also in many walks of life. $\mathrm{He}$ was born in 1822 , educated at Rugby, and entered the Royal Military Academy at the age of fifteen; here he had a most distinguished career, and obtained his commission in the Royal Engineers in 1840 , taking a first prize in every subject of the examination.

He entered public life in 1847 as secretary to the Commission that investigated the application of iron to railway structures, and soon afterwards became an inspector of railways and secretary of the railway department of the Board of Trade. This position he resigned in 1860 , but his knowledge of railway matters led to his still carrying out a good deal of important work in connection with railways. Perhaps the most important of these was a series of experiments for testing automatic brakes, carried out in 1878 and 1879 . The results of these experiments were brought by him before the Institution of Mechanical Engineers in a series of papers, which have ever since ranked among the standard works of reference for engineers. 
He also rendered most important services to submarine telegraphy, acting as chairman of a Committee appointed by the Government to investigate the reasons for the failure of the Atlantic cable of 1858 , and the Red Sea and Indian cable; the report of this Committee, issued in I86I, is recognised as the "most valuable collection of facts, warnings and evidence ever compiled concerning submarine cables."

In $\mathrm{I} 860$ he was appointed Assistant-Inspector-General of Fortifications, and two years later he became AssistantUnder-Secretary of State for War. After his retirement from this post he became Director of Works and Public Buildings in Her Majesty's Office of Works, an appointment which he held until 1875 .

He was for twenty-five years General Secretary of the British Association, and this fact alone should win for him the gratitude of scientific men; and he only resigned that post to be appointed President in 1895 . But sanitary matters especially attracted his attention. As Captain Galton he invented the grate which still goes by his name, and which introduced a new idea. He never patented this invention, so it was to no one's interest to push it ; had it not been for this state of things, there is no doubt that it would long ago have come into general use, and would probably have brought a large fortune to its inventor.

He was connected with all the great sanitary undertakings of the last forty years or more. Whether it was the main drainage of the metropolis, or the improvement of the health of the army, or the training of sanitary inspectors, Sir Douglas Galton was always to the fore; in fact, no scheme connected with sanitary improvement has for many years past been considered complete without his co-operation. He strongly opposed the scheme of the Metropolitan Board of Works by which the sewage of London was discharged into the river at Barking and Crossness, urging that a nuisance would be created by it, and that it should be taken down as far as Sea Reach in order to be diluted with a much larger volume of water. The result amply justified his anticipations, and showed the correctness of his judgment.

$\mathrm{He}$ was one of the early supporters of the Parkes Museum, and also the leading spirit of the Sanitary Institute, of the Council of which he was chairman for the second time at his death; but to enumerate the positions he filled, and filled with distinction, would take up too much space.

He was elected an Honorary Member of the Institution of Civil Engineers in 1850 , and a Fellow of the Royal Society in 1859 , and received the honorary degrees of D.C.L. from the University of Oxford, and LL.D. from Durham and from Montreal. He was made a C.B. in I 865 , and a K.C.B. in 1887 .

Personally he was a kindly and genial man who made many friends, and few, if any, enemies, and his "amiable personality," a phrase happily applied to him by one of the foreign delegates of the International Congress of Hygiene and Demography in 1891, of the executive committee of which he was chairman, will be much missed.

W. H. C.

\section{PROFESSOR OTHNIEL CHARLES MARSH.}

U UST within a period of two years the United States $\int$ has lost two of its most distinguished palaentologists, Cope having passed away on April I2, I 897, while the death of Marsh is announced to have taken place on the 18 th of March of the present year. The two names have been associated (not always, unfortunately, in the most amicable manner) in connection with the marvellous discoveries of strange and gigantic creatures which have rendered the last five-and-twenty years unique in the history of palæontology; and it may be regarded as NO. I 535, VOL. 59] certain that none of their successors, however able they may be, will ever attain the world-wide celebrity accorded to these distinguished workers. For as Owen and Huxley are the two English biologists whose names have become household words, so Marsh and Cope are the popular representatives of Trans-Atlantic palæontological investigation.

Marsh, who was considerably the elder of the two, was. the more familiarly known in England, from his custom of making periodical visits to Europe at comparatively short intervals. His last visit was to the Zoological Congress held at Cambridge during the past summer; and all those who then saw him could scarcely fail to notice that the hand of death had already made its grip on the once stalwart frame.

According to the information at present available to us, it appears that Marsh was sixty-eight years of age at the time of his decease. Born in the States, he recejved a large portion of his education at Yale; but he also studied geology and palæontology at various continental seats of learning, such as Berlin, Breslau, and Heidelberg, thus acquiring a wide basis of knowledge which stood him in good stead in after years. He was appointed to the chair of Palæontology in the University of Yale in the year I866; and this important post he held till his death. For many years he was also palæontologist in charge to the U.S. Geological Survey, at first under Clarence King and then J. W. Powell ; but of his subsequent relations to that department we are not fully aware. Marsh possessed the University degrees of Ph.D., LL.D., and M.A.; and his great attainments were recognised by his affiliation to many European scientific bodies. In this country, he was a Fellow of the Geological Society, having been elected as far back as 1863 , and in 1877 having received the first award of the then newly-founded Bigsby Medal. In I88 $\mathrm{I}$ he was elected a Corresponding Member of the Zoological Society of London; and he was likewise on the roll of the British Association, whose meetings he on several occasions attended. A nephew, we believe, of the late George Peabody, Marsh was a man of considerable, if not large fortune ; and to this circumstance is partly owing the vast extent of the collections he succeeded in accumulating.

Prout's discovery in 1846 in the Miocene strata of Western America of remains belonging to the animals now known as Titanotherium was the commencement of the investigations which made celebrated the names of Leidy, Cope, and Marsh. But it was not till 1869 that the older beds on the western flanks of the Rocky Mountains were explored, and the Eocene mammals of America thus brought to light. It was in this year that the explorations in the neighbourhood of Fort Bridger at the base of the Uinta Mountains were commenced; and it was from this district that the Uinta, Bridger, Wasatch, and Wind River beds received their names. The first worker in this field of research was Leidy, whose labours were mainly confined to the fauna of the higher Tertiary beds of the "Mauvaises Terres" to the east of the Rocky Mountains. By 1862 , in which year appeared his paper on Eosaurus from the Carboniferous of Nova Scotia, Marsh was, however, well to the fore as a working palæontologist, and shortly after the opening-up of the Fort Bridger district as a fossiliferous locality he was almost at the zenith of his fame ; the year 1872 being notable as the one in which the now well-known names Ichthyornis and Hesperornis were applied to the toothed birds of the Kansas Cretaceous. Some idea of the rapidity with which specimens were collected and described may be gathered from the fact that between the years 1862 and 1879 Marsh proposed no less than I34 new generic terms for the fossils he accumulated and described. That many of these names subsequently turned out to be synonyms, in no way detracts from the energetic character of his labours. For it must be remembered that between 1869 